\title{
Living Labs and Partnerships for Progress: How Universities can Drive the Process towards the Sustainable City
}

\author{
Federico Delfino ${ }^{1,2 *}$ and Paola Laiolo ${ }^{1}$ \\ ${ }^{1}$ DITEN-Department of Naval, Electrical, Electronic and Telecommunication Engineering, University of Genoa, Italy \\ ${ }^{2}$ CenVIS-Service Centre (CenVIS) for the management of Ventimiglia, University of Genoa, Italy
}

Submission: March 22, 2019; Published: April 02, 2019

*Corresponding author: F Delfino, DITEN-Department of Naval, Electrical, Electronic and Telecommunication Engineering, University of Genoa, Italy

\begin{abstract}
Universities can play an active role in facilitating the deployment at a wide scale of the sustainability concept, strictly cooperating with public-private institutions and civil society. Following this path, the University of Genoa, Italy, decided to transform its Savona Campus into a Living Lab aimed at creating a model of a sustainable urban district, to be replicated at the city level with specific implementation projects. Different actions on sustainable energy, smart environment and social health \& wellbeing have been deployed: energy efficiency interventions, smart grid connected to a zero-emission building, electrical mobility and outdoor sport activities. All the projects have been developed with the active involvement and the empowerment of the Campus community (students and faculty) and thanks to important collaborations with local public institutions and industrial companies. The main partnerships towards the achievements of sustainability goals are with the Italian Electricity company, Enel S.p.A. and with the Savona Municipality, which enabled the extension of the Smart City experimentation to Savona population. These projects are constantly promoted and disseminated to university students during lessons, to visiting schools and civil society during specific events on sustainability topics inside the city.
\end{abstract}

Keywords: Smart city; Living lab; Sustainability

\section{Introduction}

During the last two decades, many cities around the world started to improve their urban infrastructures and services by resorting to the opportunities offered by state-of-the-art innovative technologies and according to the "sustainability" paradigm in order to offer higher life quality conditions to their citizens [1-6]. This is the concept of the new sustainable smart cities, intended as urban spaces highly permeated by the contribution of a citizen and society-oriented technology [7]. Smart cities today stand for a multidisciplinary subject of interest with several sectors of development, namely energy, intelligent buildings, mobility, environment, low-impact infrastructures, participated governance, education, healthcare and wellbeing. As a result, these innovative and sustainable urban areas have been studied not only by scholars in architecture and urban planning, but also by researchers in other fields, such as the social sciences (economy, geography), and the technical ones (computer science, electrical and civil engineering) [8].
Universities can play an active role in increasing the public awareness about the benefits provided by an environmentally sustainable approach in planning urban regeneration, strictly cooperating with local institutions and industrial companies [9]. They can test at the campus level new services and technologies becoming Living Labs [10-12], i.e. open-innovation environments typically characterized by private - public partnerships aimed at implementing and demonstrating new technologies and systems for urban applications. In this context, the University of Genoa (UNIGE), Italy, recognizes, in its Charter, sustainability as one of the main pillars for its future evolution, in strict connection with the development lines of the surrounding territory. In particular, UNIGE decided to make its Savona Campus, which is comparable to a small city quarter (area of about $60.000 \mathrm{sqm}$ and population of 2300 people), evolve into a demo site of a sustainable urban district in order to: 
a) Embed sustainability in several aspects of the university (education, research and operations);

b) Disseminate the sustainability knowledge not only to Campus users but also to local citizens and schools;

c) Create a model of sustainable district to be replicated at the city level $[14,15]$.

The "Living Lab Smart City" started to be implemented on 2011, when the University of Genoa conceived the "Energia 2020" project (www.energia2020.unige.it), an integrated action on the Sustainable Energy sector developed in partnership with the Italian Ministry of Education, University and Research, the Italian Ministry for the Environment and the Liguria regional government. Such project allowed the implementation at the Campus level of "smart" urban energy infrastructures like a polygeneration microgrid (February 2014) and a zeroemission building (December 2017), totally automated and interacting with its users. Thanks to the presence of these pilot plants, the University of Genoa succeeded in establishing the following two important collaborations, respectively in 2016 and 2017: a "Research, Development and Demonstration" (R\&D\&D) agreement with the Italian Electricity company, Enel S.p.A., aimed at testing and demonstrating to population and institutional stakeholders the sustainable energy technologies for the Cities of the Future; an Institutional Agreement with Savona Municipality, aimed at exporting into the city the paradigm "Innovation for a more Sustainable Life", with real applications on energy, environment, health \& wellbeing areas.

Table 1 summarizes the "Living Lab Smart City" achievements in different city sectors; while Figure 1 shows some photos of the Savona Campus about green areas, renewable energy technology and outdoor sport infrastructures. More information about the projects and actions developed inside Savona Campus can be found in Bracco et al. [16].

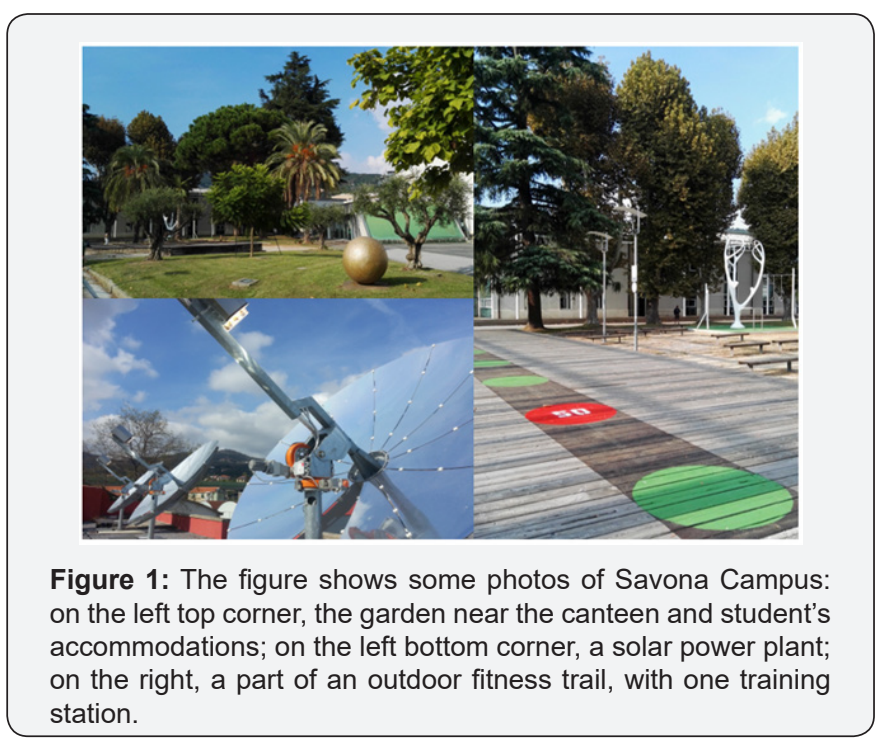

Table 1: Smart City achievements of Savona Campus-University of Genoa.

\begin{tabular}{|c|c|}
\hline Smart City Sector & Achievements of Savona Campus \\
\hline \multirow{3}{*}{ Sustainable Energy } & Creation of a Smart Microgrid managed by a "central brain", the Energy Management System \\
\hline & Energy production from renewable sources and cogenerating units \\
\hline & Energy-efficiency interventions in public buildings \\
\hline \multirow{3}{*}{ Smart Mobility } & 4 charging stations ( 2 Grid to Vehicle and 2 Vehicle to Grid) \\
\hline & 4 electric vehicles ( 2 bikes and 2 cars) \\
\hline & 73 bike parking lots \\
\hline \multirow{2}{*}{ Smart Buildings } & Construction of a Smart Energy Building managed by a "local brain", the Building Management System \\
\hline & High level of automation and interaction with the users \\
\hline \multirow{5}{*}{ Sustainable Environment } & Improvement of green areas and biodiversity \\
\hline & Vertical hydroponic garden \\
\hline & Energy \& water saving irrigation system \\
\hline & Rainwater collection \\
\hline & Improvement of waste collection \\
\hline \multirow{4}{*}{$\begin{array}{l}\text { Health, Wellbeing and Social } \\
\text { Integration }\end{array}$} & Creation of a technological gym with some machines able to produce electricity \\
\hline & Creation of an outdoor fitness trail \\
\hline & New project ongoing: National Sport Hub for sea and water activities \\
\hline & Creation of an integrated facility for the training of Paralympic athletes \\
\hline
\end{tabular}

\section{Conclusion}

This short paper has summarized the actions put in place by the University of Genoa in order to drive the process in the society towards the Sustainable Smart City. Open-air demonstration activities have a positive impact in facilitating the learning about the social and environmental benefits brought by the innovative and sustainable technologies. In particular, the visits to the Savona Campus by citizens, schools and institutional 
stakeholders together with the projects implemented with the collaboration of the national electricity company, contributed to the widespread diffusion of the "Sustainable Life" awareness. As a result of this, many Savona citizens decided to reach out to the Campus administration in order to get more information about the new technologies and their costs, asking to become involved in this evolutionary process. From an educational point of view, university students and pupils from local schools are able to make an experience of applicative learning having the evidence for it around the Campus and feeling committed to adopt the observed best practices and correct behaviours into their everyday lives. We strongly believe that the best way to disseminate the sustainability culture inside the society is to teach it to young people, the citizens of the future Smart Cities.

\section{References}

1. Jong M, Joss S, Schraven D, Zhan C, Weijnen M (2015) Sustainablesmart-resilient-low carbon-eco-knowledge cities; making sense of a multitude of concepts promoting sustainable urbanization. J Clean Prod 109: 25-38.

2. Trindade EP, Hinnig MPF, Da Costa EM, Marques JS, Bastos RC, et al. (2017) Sustainable development of smart cities: A systematic review of the literature. J Open Innov Technol Mark Complex, pp. 3-11.

3. Angelidou M, Karachaliou E, Angelidou T, Stylianidis E (2017) Cultural heritage in smart city environments. Int Arch Photogramm Remote Sens Spat Inf Sci 42: 27-32.

4. Bibri SE, Krogstie, J (2017) Smart sustainable cities of the future: An extensive interdisciplinary literature review. Sustain Cities Soc 31: 183-212.

5. Bibri SE (2018) A foundational framework for smart sustainable city development: Theoretical, disciplinary, and discursive dimensions and their synergies. Sustain Cities Soc 38: 758-794.

6. Cocchia A (2014) Smart and Digital City: A Systematic Literature Review. In Smart City: How to Create Public and Economic Value with
High Technology in Urban Space. In: Dameri R, Rosenthal-Sabroux C (eds.) Springer: Cham, Switzerland, pp. 13-43.

7. D'Auria A, Tregua M, Vallejo-Martos MC (2018) Modern Conceptions of Cities as Smart and Sustainable and Their Commonalities. Sustainability 10(8): 2642.

8. Angelidou M (2017) The Role of Smart City Characteristics in the Plans of Fifteen Cities. J Urban Technol 24: 3-28.

9. Hambleton R (2014) From the smart city to the wise city: The role of universities in place-based leadership. In Proceedings of the Smart City: New Media, Social Participation and Urban Governance, Shanghai, China, 5-7 June 2014; Shanghai University: Shanghai, China.

10. Cosgrave E, Arbuthnot K, Tryfonas T (2013) Living Labs, Innovation Districts and Information Marketplaces: A Systems Approach for Smart Cities. Procedia Comput Sci 16: 668-677.

11. Schaffers H, Komninos N, Pallot M, Trousse B, Nilsson M, et al. (2011) Smart cities and the future internet: Towards cooperation frameworks for open innovation. In the Future Internet Assembly; Springer: Berlin/ Heidelberg, Germany, pp. 431-446.

12. Bergvall-Kåreborn B, Ståhlbröst A (2009) Living Lab-An Open and Citizen-Centric Approach for Innovation. Int J Innov Reg Dev 1: 356370 .

13. Delfino F, Procopio R, Rossi M, Bracco S, Brignone M, et al. (2018) Microgrid Design and Operation: toward Smart Energy in Cities; Artech House: Boston, MA, USA

14. Bracco S, Delfino F, Pampararo F, Robba M, Rossi M (2016) A pilot facility for analysis and simulation of smart microgrids feeding smart buildings. Renew Sustain Energy Rev 58: 1247-1255.

15. Bracco S, Delfino F, Ferro G, Pagnini L, Robba M, et al. (2018) Energy planning of sustainable districts: Towards the exploitation of small size intermittent renewables in urban areas. Appl. Energy 228: 2288-2297.

16. Bracco S, Delfino F, Laiolo P, Morini (2018) A Planning \& Open-Air Demonstrating Smart City Sustainable Districts. Sustainability 10(12): 4636.

Your next submission with Juniper Publishers will reach you the below assets

- Quality Editorial service

- Swift Peer Review

- Reprints availability

- E-prints Service

- Manuscript Podcast for convenient understanding

- Global attainment for your research

- Manuscript accessibility in different formats

( Pdf, E-pub, Full Text, Audio)

- Unceasing customer service

Track the below URL for one-step submission https://juniperpublishers.com/online-submission.php 